\title{
Virtual Laboratory Based Guided Inquiry: Viscosity Exsperiments
}

\author{
Wawan Kurniawan ${ }^{1}$, J. Jufrida ${ }^{2}$, Fibrika Rahmat Basuki ${ }^{3}$, Rima Ariani ${ }^{4}$, Olva Fitaloka ${ }^{5}$ \\ Physics Education Study Program, Universitas Jambi, Jambi, Indonesia ${ }^{1,2,3,4}$, \\ Mathematic Education Study Program, Universitas Jambi, Jambi, Indonesia ${ }^{5}$ \\ kurniawan_wawan@unja.ac.id ${ }^{1}$, jufrida_66@yahoo.com ${ }^{2}$, fibrikabika@yahoo.com³, \\ rimaafriani@gmail.com ${ }^{4}$, olvafitaloka@gmail.com ${ }^{5}$
}

Received: June 26 ${ }^{\text {th }}, 2019$. Revised: August $18^{\text {th }}, 2019$. Accepted: August $22^{\text {th }}, 2019$

Keywords :

Vir-Lab; Guided Inquiry;

Viscosity Experiements

\begin{abstract}
This study aims to develop a virtual laboratory (Vir-lab) based guided inquiry on viscosity experiments and know the students' perceptions of the products developed. This study was a research and development using $4 D$ model that consists of four stage: define, design, develop, disseminate. The participants were two material experts, two media experts, and 43 students. Data collection used expert assessment sheet and student response questionnaire. The data were analyzed descriptively. The result of this study was a Vir-lab which was packaged in e-book form with $3 D$ effects. The activities in the Vir-lab are designed based on the syntax of guided inquiry. The Vir-lab contains goals, problem formulations, theories, hypotheses, tutorial videos, virtual experiments, experimental data, data analysis, results, and conclusions. The results of the material expert obtained a score of 45 with a very good category and media experts obtained a score of 66 with a very good category, and the results of the students' perception test obtained a score of 60.65 with a very good category. The conclusion of this study shows that the Vir-lab is valid and suitable for use as a medium for learning physics.
\end{abstract}

\section{INTRODUCTION}

The laboratory has an important role in science learning [1,2]. In physics learning, laboratories can help students understand concepts, define and explain law and theory through hand on activity [3]. Laboratory experiments contribute positively to students in understanding science, critical thinking, manipulative skills, inquiry, discovery, and problem-solving abilities in physics [4]. But in developing countries such as Indonesia, the limitations of laboratory equipment and other supporting facilities are the main problems [5]. The limitations of laboratory equipment cause laboratory experiment activities to be less optimal so that students do not get direct experience to find or prove the concept of physics. In addition, time management, large class sizes and the amount of material that will be discussed are obstacles that are often in the practical activity. On the other hand, the development of ICT has changed the paradigm of traditional (face-to-face) learning into distance learning (anywhere and anytime). But for science fields, often require laboratory exercises to provide effective acquisition and hands-on experience skills [6]. 
The alternative to solve this problem through a virtual laboratory (Vir-Lab).Vir-lab is an interactive science situation with a computer application in the form of a science experiment simulation. Virtual laboratory or simulation-based laboratory (SBL) are experimental activities on desktop computers by manipulating objects and variables such as real experiments [7]. The virtual lab provides opportunities for diversifying of activities and the use of various laboratory instruments in different experiments. The students have chances to carry out experiments including testing the cases, observing, and recording the results in a peaceful and safe environment [8,9]. Virtual laboratories can be used as alternatives to still be able to do physics experiments. Besides being cheaper and affordable, it is also safer for students as users. Students can also experiment wherever and whenever they need. Virtual lab is to provide students knowledge of the physical phenomena to reduce the limitations of the hands-on labs, such as the operating conditions,i.e., time, temperature, and number of cells, and to provide them with values for the parameters of a real system that can help with a critical discussion of the measured results [10].

Vir lab is not a substitute for the real lab, but as a supporter of hand on activity. Science learning that combines physical labs and augmented virtual laboratory can help students develop and connect ideas to explain gas phenomena [11]. There is parity between the hands-on condition, Serious Educational Games (SEGs), and the virtual reality (VR) conditions in learning outcomes and cognitive processing. But learning through VR and SEGs shows higher cognitive dynamics, increased attention, and critical thinking obtained in the subjects involved [12]. An electronic concept-mapping tool had significant advantages in supporting the construction of concept maps representing causal relationships in a dynamic system. The electronic tool also meant that the concept maps were more consistent in structure and names of nodes [13].

The existing Vir-labs are PhET Interactive Simulations and Amrita Olabs. The PhET Interactive Simulations application can be downloaded and can be used offline but there is no integrated guide in the virtual laboratory. This makes it difficult for users to understand how to use PhET Interactive Simulations. On Amrita Olabs site there is a way to use virtual laboratories and demonstration videos but the application cannot be downloaded so it requires users to connect to the internet. This causes the ineffectiveness of using a virtual laboratory. Therefore, it is necessary to develop an electronic guide that is integrated into a virtual laboratory.

Design and implement 3D virtual labs, which are considered as a low-cost alternative to educators and students, in science E-learning [14]. This study focuses on the virtual assembly of instruments, the realization of dynamic 3D gauges, and the setup of emulation-based systems, which are key factors to provide students with the high-immersion 3D virtual lab. It also describes the setup of the network environment of this virtual lab; in this network, the server controls the options, user operations and the processes of experiments. Developing Of a Virtual Laboratory for control systems simulation [15]. The simulation environment was built on a transparent modeling platform that allowed the users to easily modify the controller parameters. The human-machine interface employed both two and threedimensional graphics displays enabling real-time monitoring of the quadrotor's trajectory. The Virtual Laboratory was modulated for usage by multiple student groups. The results from these experiments indicate that this Virtual Laboratory may be easily integrated into control and simulation courses and projects for undergraduate engineering students. Developing blended learning model using projectbased learning via virtual science laboratory in a science classroom for students in secondary schools [16]. The model could lead students to understand sciences lessons easier and enable to do experiments in lesser time and encourage them to create new further experiments with curiosity. There are five modules in the model which are 1) Student Module 2) Instructor Module 3) Blended Learning Module from Project-Based Learning and Active learning for students to conducting science projects and to check how much they understand what they have learned 4) Virtual Laboratory Module and 5) Assessment Module. 
The purpose of this study was to develop a virtual laboratory based guided inquiry: viscosity experiment. Vir-lab developed has differences with existing Vir-labs. Vir-lab developed packaged in the form of an e-book with 3D effects. This Vir-lab contains a practical guide, video tutorial, virtual laboratory, data analysis, and results and conclusions. This virtual laboratory was developed using a 3D Professional Pageflip program that is supported by the Camtasia studio 8 program for the production of video demonstrations, and Adobe Flash for making virtual laboratories. The developed Vir-lab was designed to integrate the guided inquiry model. Guided inquiry is an effective way to vary the atmosphere of classroom learning patterns. Guided inquiry learning is group learning where students are given the opportunity to think independently and help each other with friends [17]. Inquiry-based virtual physics lab is able to introduce design and analysis of virtual physics experiments, allowing students to gain deep profound process skills, comprehensive skills, and reflection skills in scientific inquiry [18].

\section{METHOD}

\section{Procedure}

This research was research and development using 4D model. The development stage consists of define, design, develop, and disseminate [19]. This research was conducted only to develop.

The define phase consists of five stages: front-end analysis, learner analysis, task analysis, concept analysis, and specifying instructional objectives. Front-end analysis aims to find out the problems in learning physics specifically viscosity. Learner analysis was conducted to determine the characteristics of students who ware the subject of research. Task analysis was carried out to determine the expected learning outcomes. Concept analysis was carried out to identify the main concepts taught in viscosity experiments and design concept maps. Specifying instructional objectives ware formulated for the specific purpose of the viscosity experiment.

In the design stage, a virtual laboratory prototype was designed. The steps taken ware media selection, format selection and initial design. The initial design was realized in the form of storyboards.

The virtual laboratory development phase consists of two stages: expert validation and development testing. Expert validation consists of media experts and material. Development testing was carried out on students to find out the perception of a virtual laboratory product.

\section{Subject}

Subjects in this study were two material experts and two media experts as validates and $4^{\text {th }}$ semester students of Physics Education department of Jambi University consisting of 43 students.

\section{Instrument}

This expert assessment sheet used an open assessment so that experts can provided improvement suggestions on the developed virtual laboratory products. To find out the quality of the product had developed, this assessment sheet also used a likert scale with 4 scales $(1=$ very poor, $2=$ not good, 3 $=$ good, and $4=$ very good). The aspect of assessment for material experts included the suitability of the material with the learning objectives, the accuracy of the material and the content, the material update, and the components of language. The material expert assessment instrument consists of 4 indicators with 14 questions. Assessment aspects for media experts included cover design, content design, application design, presentation and operation components. The media expert assessment instrument consists of 5 indicators with 22 questions.

The student response questionnaire was used to determine the student's perception of the virtual laboratory product. This questionnaire used a likert scale with 4 scales $(1=$ very poor, $2=$ not good, 3 $=$ good, and $4=$ very good. The assessment aspect of this questionnaire included a virtual guide design cover laboratory, virtual guide content design, guide software design virtual laboratory, presentation component, ease of operation, and linguistic component. This questionnaire consists of 6 indicators with 20 questions. Validity of this scale was conducted by two reviewers at physics 


\section{Virtual Laboratory Based Guided Inquiry: Viscosity Exsperiments Wawan Kurniawan, J. Jufrida, Fibrika Rahmat Basuki, Rima Ariani, Olva Fitaloka}

education department. The reviewers ware asked to verify that it was appropriate for the purpose of the study and that the items were clear, readable, and accurate. Reliability was calculated using Cronbach's Alpha (0.864).

Data Analysis

Qualitative data in this study ware suggestions from validators of material experts and media experts. The data collected was analyzed descriptively. Quantitative data were the results of expert assessments and student questionnaire scores. The data were analyzed using descriptive statistics, the analysis was carried out with SPSS 23.0

\section{RESULTS AND DISCUSSIONS}

\section{Product Specification}

The results of this study are the virtual laboratory based guided inquiry on viscosity experiments. The virtual laboratory product specifications are developed as follows:

1. The Vir-Lab are packaged in the form of e-books with 3D effects.

2. The Vir-Lab was developed using a 3D PageFlip Professional, Adobe Flash, and Camtasia Studio 8 program.

3. The Vir-Lab output was .exe format files that can be run on a PC without having to install software 3D PageFlip Professional.

4. The Vir-Lab was integrated three in one that consist of guides, virtual experiments and experimental reports in one product.

5. The Vir-Lab is prepared based on the syntax of guided inquiry. It contains goals, problem formulations, theories, hypotheses, tutorial videos, virtual experiments, experimental data, data analysis, results and conclusions.

6. The Vir-Lab was developed using Indonesia language.

Vir-lab was designed for students to learn independently. Learning activities begin with problems. Students are guided to learn the theoretical basis first so that they can formulate hypotheses according to the problems proposed. To increase understanding, students can observe experimental videos in real terms. To test the hypothesis, students can conduct virtual experiments. Viscosity experiments are designed in three stages: measuring the diameter of a solid ball, measuring the mass of a solid ball, and measuring time (the length of the solid ball moves from point A to point $B$ ) when dropped in a fluid. The independent variable is the diameter of the solid ball and the type of fluid. The dependent variable is time (long solid ball moves from point A to point B). Experiments can be done with two different designs. Experiment I, the effect of fluid density on time (long solid balls move from point A to point B). In experiment I, the control variable is a solid ball used the same. Experiment II, the effect of spherical diameter on time (long solid balls move from point A to point B). In experiment II, the control variable is the same type of fluid used. After conducting the experiment, students can calculate the fluid viscosity coefficient. The Vir-lab was designed an integrated manner that combines guides, virtual experiments and experimental reports in one product. Students can write experimental data, analyze data, results and discussion, and conclusions. The final result can be printed or emailed to the lecturer. The following is a virtual laboratory product for viscosity experiments.

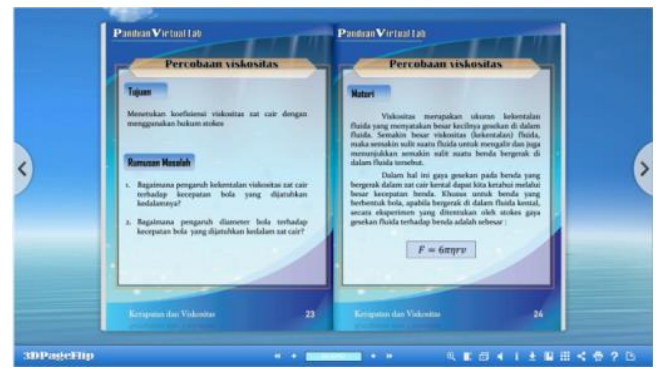


JIPF, Vol. 4 No. 2, September 2019

Figure 1. Virtual laboratory introduction page

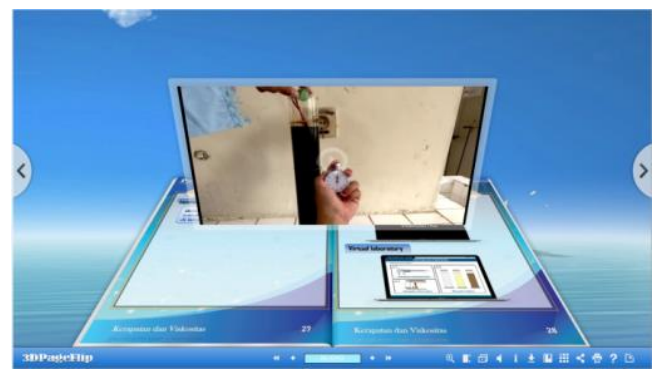

Figure 2. The experimental video of viscosity

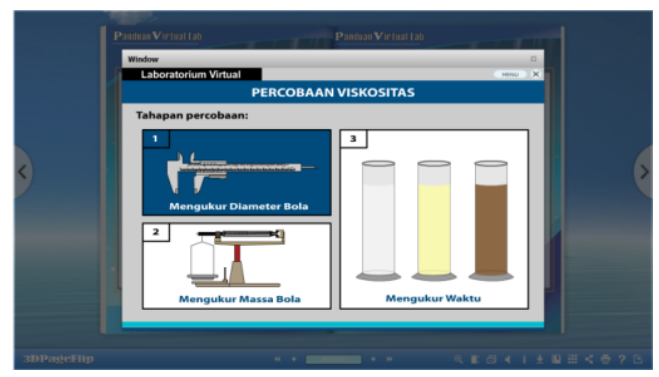

Figure 3. Measurement of diameter, mass and time in a viscosity experiment

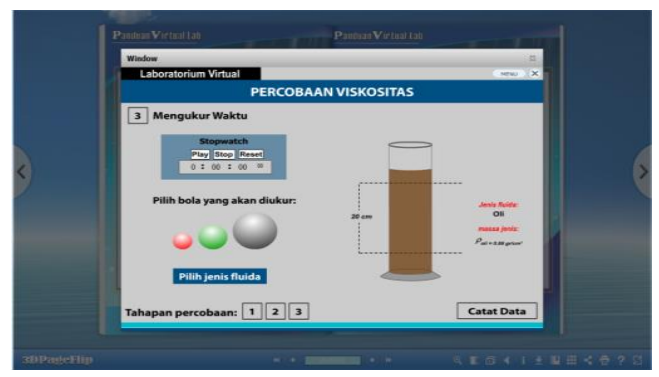

Figure 4. The virtual experiment of viscosity

\section{Expert Assessment}

The virtual laboratory that had been made was validated by material experts and instructional media experts. The expert team assessed the feasibility of a virtual laboratory product by providing assessments and suggestions for improvement. The validation process was carried out twice, assessment and suggestions from experts are used as the basis for virtual laboratory improvements. The final assessment of the material expert validation obtained a score of 45 with a very good category and media experts obtained a score of 65 with a very good category. The product evaluation results from the experts are very good so that the Vir-lab is valid and proper to use. Vir- lab products that have been developed are suitable for field trials.

\section{Students Response}

The development test was conducted to find out students' perceptions of the virtual laboratory. This trial was carried out by giving virtual laboratory products to 43 respondents. Students ware asked to use a virtual laboratory on viscosity experiments. After using the virtual laboratory, students filled out the questionnaire given. Questionnaire score results, namely for the virtual laboratory cover design indicator is 12.72 , the indicator of the virtual laboratory content design is 18.95 , the virtual laboratory application design indicator is 13.05 , the presentation component indicator is 3,21 , the ease of 
operation indicator is 3.19, and the linguistic component indicator is 9.60. All indicators have very good categories. Students are more interested in learning by using vir-lab because they are interactive and learn independently. Students can conduct experiments virtually, analyze data, results and discussions, and conclusions directly. The final results can be printed or emailed to the lecturer. Virlab is also equipped with a video demonstration of a real experiment. Vir-lab can make learning more interesting, more interactive, the amount of teaching time can be reduced, the quality of learning can be improved and the teaching and learning process can be done anywhere and anytime [20]. The use of virtual laboratories allows students to learn more actively and more enthusiastically because the visualization of this media is displayed attractively [3,21]. Virtual laboratories can make learning more interesting, interactive, and the quality of learning can be improved and the practicum process can be carried out where anytime and anytime [22-24] The use of vir-lab can increase student involvement in learning rather than activities carried out using blackboards and chalk in traditional classrooms [25].

Based on the results of the virtual laboratory development on viscosity experiments, it is expected to be used to support hand on activity. The experiments should be supported with ICT through computer simulation and the internet connection to eliminate the limitations in conventional laboratory [26]. Physical learning uses computer simulation (virtual) or a combination of hand on activity is better in understanding the concept of physics [27,28]. Physics teaching using the Istanbul University Virtual Laboratory (IUVIRLAB) has a significant difference in learning achievement compared to conventional learning. It was found that IUVIRLAB group have the higher score achieved and more successful in preventing of misconceptions about electromagnetic field and magnetism [29].

Vir-lab can be used anywhere and anytime and can provide opportunities for students to actively learn independently without the help of assistants [24]. Virtual laboratory provides a positive effect on learning outcomes, learning becomes more interesting and interactive, can improve creativity, and problem solving abilities [22,23,30,31]. The use of a virtual laboratory allows students to learn more actively and more enthusiastically because the visualization of this media is displayed attractively [3]. On the other hand, vir-lab gives students the opportunity to experiment repeatedly until they fully understand and at a time and place that is comfortable for them.

The developed Vir-lab was designed to integrate the guided inquiry model. Learning activities are designed according to the guided inquiry syntax. The guided inquiry model has been widely used in science learning and shows a positive influence. The inquiry-based science education had a positive and higher levels of effects of students' academic achievement, science process skills and attitudes towards science [32]. This research is relevant to Wang et al., who design the six main learning modules namely (1) introduction to the topic, (2) direct experiment, (3) virtual experiment, (4) team work, (5) the actual application and (6) model adjustments [18]. The experimental teaching showed that MBI and MBI-VPL pedagogy were more effective in developing student scientific inquiry skills compared to traditional methods, with significant improvements in the performance of process skills, comprehensive skills, learning attitude, communication skills, and reflection skills. The MBI-VPL pedagogy was able to introduce virtual physics experiment design and analysis, allowing students to gain in-depth practice of process skills, comprehensive skills, and reflection skills of scientific inquiry.

\section{CONCLUSION AND SUGGESTION}

The product that has been developed was a vir-lab based guided inquiry in the viscosity experiment. Vir-Lab are packaged in the form of e-books with 3D effects. This Vir-Lab product integrates guides, virtual experiments and experimental results reports in one product.Vir-Lab was developed using a 3D PageFlip Professional, Adobe Flash, and Camtasia Studio 8 program. Output Vir-Lab in the form of .exe format files that can be run on a PC without having to install software 3D PageFlip Professional.Vir-Lab is prepared based on the syntax of guided inquiry. Vir-Lab contains goals, problem formulations, theories, hypotheses, real experiment videos, virtual experiments, experimental data, data analysis, results and conclusions. The results of the material expert validation obtained a 
score of 45 with a very good category and media experts obtained a score of 65 with a very good category, and the results of the students' perception test obtained a score of 60.65 with a very good category. Vir-Lab is feasible for field trials to determine effect on increasing mastery of the concepts of physics. Vir-Lab is used as a lab assistant in real terms in order to improve the understanding of physics concepts.

\section{REFERENCES}

[1] Hofstein, A and Lunetta, V. N. (1982). The Role of the Laboratory in Science Teaching: Neglected Aspects of Research. Review of Educational Research, 52(2 ):201-217.

[2] Forcino, F. L. (2013). The Importance of a Laboratory Section on Student Learning Outcomes in a University Introductory Earth Science Course. Journal Of Geoscience Education, 61, : 213221.

[3] Bajpai, M. (2013). Development conceps in physics through virtual lab exsperiment: An effectiveness study. An International Journal Of Education Technology, 3 (1): 43-50.

[4] ÇAKIROĞLU, Ö . (2006). The Role And Significance Of The Physics Laboratories In Physics Education As A Teacher Guide. Hasan Ali Yücel Eğitim Fakültesi Dergisi, 3(2): 1-13.

[5] Abdullah, A. G., Hakim, D. L., Auliya, M. A., et al. (2018). Low-cost and Portable Process Control Laboratory Kit.TELKOMNIKA, 16 (1): 232-240.

[6] Potkonjak, V., Gardner, M., Callaghan, V., et al. (2016). Virtual Laboratories for Education in Science, Technology, and Engineering: a Review. Computers \& Education, 95: 309-327.

[7] Chien, K. P., Tsai, C. Y., Chen, H. L., Chang, W.H., \& Chen, S. (2014). Learning differences and eye fixation patterns in virtual and physical science laboratories. Computers \& Education, 82: 191-201.

[8] Ambusaidi, A., Al Musawi, A., Al-Balushi, S., Al-Balushi, K. (2018). The Impact of Virtual Lab Learning Experiences on 9th Grade Students' Achievement and Their Attitudes Towards Science and Learning by Virtual Lab. Journal of Turkish Science Education (TUSED), 15(2): 13-29.

[9] Iovan,M., Surianu, F. D., \& Matei, F.M. (2015). Virtual Laboratory for Power Quality Study.WCES 2014, Procedia - Social and Behavioral Sciences, 191: 2798-2802.

[10] Domínguez, J. C., Miranda, R., González, E. J., Oliet, M., \& Alonso, M. P. (2018). A virtual lab as a complement to traditional hands-on labs: Characterization of an alkaline electrolyzer for hydrogen production. Education for Chemical Engineers, 23: 7-17.

[11] Chiu, J. L., DeJaegher, C. J \& Chao, J. (2015). The Effects of Augmented Virtual Science Laboratories on Middle School Students' Understanding of Gas Properties. Computers \& Education, 85: 59-73.

[12] Lamb, R., Antonenko, P., Etopio, E., Seccia, A. (2018). Comparison of virtual reality and hands on activities in science education via functional near infrared spectroscopy. Computers \& Education, 124: 14-26.

[13] Metcalf, S. J., Reilly, J. M., Kamarainen, A. M., King, J., Grotzer, T. A., and Dede, C. (2018). Supports for Deeper Learning of Inquiry-Based Ecosystem Science in Virtual Environments Comparing Virtual and Physical Concept Mapping. Computers in Human Behavior, 87: 459-469.

[14] Liu, D., Díaz, P. V., Riofrio, G., Sun, Y, Barba, R. (2015). Integration of Virtual Labs into Science E-learning. International Conference on Virtual and Augmented Reality in Education, Procedia Computer Science, 75: 95-102.

[15] Murphy, M. D. (2016). A modular virtual laboratory for quadrotor control simulation. IFAC (International Federation of Automatic Control) Paper Online, 49 (6): 093-098.

[16] Klentien, U. \& Wannasawade, W. (2016). Development of blended learning model with virtual science laboratory for secondary students. Future Academy's Multidisciplinary Conference, Procedia - Social and Behavioral Sciences, 217: 706 - 711.

[17] Ambarsari,W., Santosa,S., \& Maridi. (2013). The application of guided inquiry learning towards basic science process skills in biology learning for VII grade students of SMP N 7 Surakarta. JurnalPendidikanBiologi, 2(1): 81-95.

[18] Wang, J., Guo, D., \& Jou, M. (2015). A study on the effects of model-based inquiry pedagogy on students' inquiry skills in a virtual physics lab. Computers in Human Behavior,49: 658-669. 
[19] Thiagarajan, S., Semmel, D. S \& Semmel, M. I. (1974). Instructional Development for Training Teachers of Expectional Children. Minneapolis, Minnesota: Leadership Training Institute/Special Education, University of Minnesota.

[20] Rizki, R. N. (2011). Utilization of virtual laboratories and e-references in the process of learning and research in chemistry. Jurnal PHENOMENON, 1(1): 115-123.

[21] Singh, K. G. (2013). Virtual Learning Environment For Next Generation In Electronics \& Telecommunications Course. International Journal Of Technological Exploration And Learning (IJTEL), 2(3): 1-5.

[22] Herga, N. R., Grmek, M. I., Dinevski, D. (2014). Virtual laboratory as an element of visualization when teaching chemical contents in science class. The Turkish Online Journal of Educational Technology, 13(4): 157-165.

[23] Gunawan, A. Harjono, \& Sahidu, H. (2015). The development of virtual laboratory models is oriented towards problem solving skills for prospective physics teachers. Jurnal Materi dan Pembelajaran Fisika (JMPF), 5(2): 41-46.

[24] Yusuf, I., \& Subaer. (2013). Development of physics learning tools based on virtual laboratory media on the material of dualism wave at Tut Wuri Handayani High School Makasar. Jurnal Pendidikan IPA, UNNES, 2(2): 189-194.

[25] Tatli, Z. \& Ayas, A. (2013). Effect of virtual chemistry laboratory on students' achievement. Journal of Educational Technology and Society, 16(1): 159-170.

[26] Karagöz, O.,andSaka, A. Z. (2015). Development Of Teacher Guidance Materials Based On 7E Learning Method In Virtual Laboratory Environment. WCES 2014.Procedia - Social and Behavioral Sciences, 191 ( 201: 810 - 827.

[27] Zacharia, Z. C., and Olympiou, G. (2011). Physical versus virtual manipulative experimentation in physics learning. Learning and Instruction, 21: 317-331.

[28] Sarabando, C., Cravino, J.P., \&Soares, A. A. (2014). Contribution of a computer simulation to students' learning of the physics concepts of weight and mass. Procedia Technology, 13: 112121.

[29] İnce, E., Güneş, Z. O., Yaman, Y., Kırbaşlar, F. G., Yolcu, O., Yolcu, E. (2015). The Effectiveness of the IUVIRLAB on Undergraduate Students' Understanding of Some Physics Concepts.WorldConference on Technology, Innovation and EntrepreneurshipProcedia - Social and Behavioral Sciences, 195: 1785-1792.

[30] Suleman, Q., Ishtiaq, H., \&Naseer-ud-din, M. (2013). Role of instructional technology in enhancing student' educational attainment in general science at elementary level in district karak (Pakistan). Journal of Sociological Research, 4(1): 83-98.

[31] Gunawan, A. Harjono, Sahidu, H., \&Herayanti, L. (2017). Virtual laboratory of electricity concept to improve prospective physics teachers creativity. Jurnal Pendidikan Fisika Indonesia, 13(2): 102-111.

[32] AKTAMIŞ, H., HIĞDE, E, \& ÖZDEN, B. (2016). Effects of the Inquiry-Based Learning Method on Students' Achievement, Science Process Skills and Attitudes towards Science: A MetaAnalysis Science. Journal of Turkish Science Education (TUSED), 13(4): 249-261. 